\title{
Untreatable Fits of Hyperventilation/Apnea in Pitt-Hopkins Syndrome
}

\author{
Antonio Martínez Monseny ${ }^{1}$, María Pilar Póo ${ }^{2}$ and Mercedes Serrano ${ }^{1,2,3 *}$ \\ ${ }^{1}$ Genetic Medicine and Rare Diseases Pediatric Institute (IPER), Hospital Sant Joan de Déu, Barcelona, Spain \\ ${ }^{2}$ Neuropediatric Department, Hospital Sant Joan de Déu, Barcelona, Spain \\ ${ }^{3}$ U-703 Centre for Biomedical Research on Rare Diseases (CIBER-ER), Instituto de Salud Carlos III, Barcelona, Spain.
}

Submission: July 01, 2017; Published: July 17, 2017

*Corresponding author: Mercedes Serrano, Neuro pediatric Department \& Genetic Medicine, U-703 Centre for Biomedical Research on Rare Diseases (CIBER-ER), Instituto de Salud Carlos III, Passeig Sant Joan de Déu, 2, 08950 Esplugues, Barcelona, Spain, Tel: 34-93-253-2100; Fax: 34-93280-3626; Email: mserrano@sjdhospitalbarcelona.org

Keywords: Breath-holding spells; Apnea episodes; Pitt hopkins syndrome

\section{Introduction}

Pitt-Hopkins syndrome (PTHS) (MIM\#610954, ORPHA2896) is a rare autosomal dominant condition due to TCF4 gene mutation or deletion. PTHS is characterized by distinctive facial features, developmental delay, moderate-to-severe intellectual disability, epilepsy, constipation, and stereotypic movements [1,2]. Peculiarly, episodic hyperventilation and/or breath-holding while awake is presented by more than $50 \%$ of patients and less than half of them experience a spontaneous disappearance of these spells without treatment [3].

The underlying mechanism for these fits of hyperventilation/ apnea is not well understood and no clinical recommendations for their treatment have been published, despite two reports describing an amelioration of hyperventilation/breath-holding episodes with Acetazolamide [4,5]. These episodes can appear in a variable range of age and have been also reported in Rett syndrome, and are sporadically present in other Neuro developmental diseases (personal observation). However, this breathing disturbance and especially breath-holding episodes lead to a disruption in patients' normal activity, causing a discontinuation in their learning and their daily activities [5]. Furthermore, these episodes of apnea may cause cyanosis due to lower oxygen transportation, probably leading to right heart dysfunction in the long term.

Although there is no literature regarding the pathophysiology of these events in patients with PTHS, there is some information on Rett syndrome. Hagebeuk EE et al. [6] identified three groups of day time respiratory disturbances in these patients and observed hyperventilation could be followed by apnea, but apnea can also appear without hyperventilation. Although these breathing events might be influenced by behavioral issues, it doesn't seem compatible with breath holding as an only explanation of the phenomena. Clinical studies in classic Rett syndrome have shown dysphasia and cardio respiratory irregularities during the day and night, also suggesting brainstem dysfunction as a possible pathogenic mechanism behind the breath disturbances. Thus, brainstem serotoninergic neurons are known to play an important role in the arrangement of breathing rhythm and pattern, and one patient with Rett syndrome showing good response to fluoxetine and buspirone has been reported [7].

\section{Case Report}

We describe an 11-year-old girl affected by PTHS (due to a missense mutation in TCF4 gene: c.1733G>A, p.Arg578His) that developed breathing disturbances beginning at the age of eight. The hyperventilation/breath-holding episodes appeared only when she was awake. The apnea episodes last 20 to 30 seconds with oxygen decreases up to $60 \%$ registered through pulse oximeter and a holter monitor, that registered up to more than 100 hyperventilation/breath-holding episodes per hour with mild bradycardia, and only during wakefulness. As comorbidities she suffered partial complex seizures from the age of 6 and now follows antiepileptic therapy (carbamazepine $800 \mathrm{mg}$ / day). The patient underwent three cranial magnetic resonances at different ages, showing normal findings (including posterior fossa structures). 
To start with therapies, as it has been described as improving the apnea episodes associated with Rett syndrome, topiramate (150mg/day, two daily doses) was initiated, without clinical response after one month. Topiramate was interrupted and, at that time, following the only two reports found on this medical problem [4,5], she underwent Acetazolamide treatment (250mg/ day, two daily doses). Acetazolamide was well tolerated with no relevant side effects. During the first week there was transitory amelioration that disappeared soon after. Acetazolamide was stopped after 2 months of treatment. Then, we began different therapeutic assays working on different hypothetical bases to treat these spells: aripiprazol (initially $1 \mathrm{mg} /$ day and titration up to $4 \mathrm{mg}$ /day), clonidine (up to 40 micrograms in two daily doses), methylphenidate (20mg/day), and guanfacine (up to $2 \mathrm{mg} /$ day). All of these drugs were well tolerated and maintained at least 3 weeks but all of them resulted unsuccessful.

At that point in time, we again tried Acetazolamide, but using higher doses $(500 \mathrm{mg} /$ day, two daily doses) with good tolerance, but without maintained clinical response. At some point in time the family reported an interesting observation: when the girl suffers a cough, hyperventilation/apnea episodes improved. An interview revealed that they usually gave her a cough syrup based on a combination of cysteine and a phenothiazine called promethazine, an antihistamine with sedative properties. Following this clue, she underwent separated treatments with both drugs. Carbocisteine was used up to 750mg every 8 hours during three weeks without positive effect. The combination of carbocisteine and promethazine was also useless (up to $60 \mathrm{mg}$ of promethazine every 12 hours).

After the withdrawal of this last therapy, the patient underwent an upper respiratory infection without fever. Following our recommendation, parents did not give her any cough-syrup and, surprisingly, hyperventilation/breath-holding episodes also improved during this infection.

At the present time she is beginning treatment with sertraline, a drug which is increasing used for anxiety in genetic conditions, but which normally takes some weeks to demonstrate positive effects [8]. Our hypothesis now is that its effect on serotoninergic pathways may help to control apnea spells, as it was demonstrated in a girl with Rett syndrome $[7,8]$.

\section{Discussion}

At the present, we decided to communicate our unsuccessful experience, as PTHS patients with severe hyperventilation/ apnea suffer the consequences of a publication bias: negative results are less reported. This fact is evidenced in PTHS family groups in social networks, where the complaint is one of the most frequently shared by families. Conversely, there are probably many physicians that have tried some of the drugs that our patient received, perhaps without success.

With our experience we want to encourage physicians to share their knowledge and contribute to overcoming the lack of information and evidence on this important but enigmatic complication of PTHS. Interestingly, honeymoon positive effects are described in some epileptic patients when initiating new antiepileptic drugs, but we also found this to be the case in our patient; this may alert the clinician, and the families, to be cautious with initial responses to therapies in PTHS apeas that would not be maintained.

Intriguingly, viral infections (with or without fever) proved beneficial in our patient. This observation may lead one to hypothesize new mechanisms of treatment, perhaps related to inflammation or immune modulation.

Publishing negative experiences in rare conditions is very relevant as this may help to limit our therapeutic attempts, and their iatrogenic possibilities. Even publications reporting negative results may improve efficiency in our decisions and save time and suffering in the case of patients and families. Hyperventilation/breath-holding episodes in PTHS may be a refractory clinical situation that interferes with patients' activities and learning in the short-term while also leading to potential long-term consequences both in neurodevelopment and/or heart disease.

\section{Acknowledgement}

We thank the family of A.R.I. to giving us the permission for this publication.

\section{References}

1. Marangi G, Ricciardi S, Orteschi D, Lattante S, Murdolo M, et al. (2011) The Pitt-Hopkins syndrome: Report of 16 new patients and clinical diagnostic criteria. Am J Med Genet Part A 155A(7): 1536-1545.

2. Marangi G, Zollino M (2015) Pitt-Hopkins Syndrome and Differential Diagnosis: A Molecular and Clinical Challenge. J Pediatr Genet 4(3): 168-176.

3. Zweier C, Peippo MM, Hoyer J, Sousa S, Bottani A, et al. (2007) Haplo insufficiency of TCF4 causes Syndromal Mental Retardation with Intermittent Hyperventilation (Pitt- Hopkins syndrome). Am J Hum Genet 80(5): 994-1001.

4. Verhulst SL, De Dooy J, Ramet J, Bockaert N, Van Coster R, et al. (2012) Acetazol amide for severe apnea in Pitt-Hopkins syndrome. Am J Med Genet Part A 158A(4): 932-934.

5. Gaffney C, McNally P (2015) Successful use of acetazolamide for central apnea in a child with Pitt-Hopkins syndrome. Am J Med Genet Part A 167A(6): 1423.

6. Hage beuk EE, van den Bossche RA, de Weerd AW (2013) Respiratory and sleep disorders in female children with atypical Rett syndrome caused by mutations in the CDKL5 gene. Dev Med Child Neurol 55(5): 480-484.

7. Gökben S, Ardiç UA, Serdaroglu G (2012) Use of buspirone and fluoxetine for breathing problems in Rett syndrome. Pediatr Neurol 46(3): 192-194.

8. Greiss Hess L, Fitzpatrick SE, Nguyen DV, Chen Y, Gaul KN, et al. (2016) A Randomized, Double-Blind, Placebo-Controlled Trial of Low-Dose 
Sertraline in Young Children with Fragile X Syndrome. J Dev Behav Pediatr 37(8): 619-628.

This work is licensed under Creative

Commons Attribution 4.0 Licens

DOI: 10.19080/GJIDD.2017.01.555573
Your next submission with Juniper Publishers will reach you the below assets

- Quality Editorial service

- Swift Peer Review

- Reprints availability

- E-prints Service

- Manuscript Podcast for convenient understanding

- Global attainment for your research

- Manuscript accessibility in different formats

( Pdf, E-pub, Full Text, Audio)

- Unceasing customer service

Track the below URL for one-step submission https://juniperpublishers.com/online-submission.php 